\title{
Verbal Aggressiveness Exploration through Complete Social Network Analysis: Using Physical Education Students' Class as an Illustration
}

\author{
Alexandra Bekiari ${ }^{1} \&$ Nikolaos Hasanagas ${ }^{1}$ \\ ${ }^{1}$ Department of Physical Education and Sport Science, University of Thessaly, Greece. \\ Correspondence: Alexandra Bekiari, University of Thessaly, Karies, 42100, Trikala, Greece, E-mail: sandrab@pe.uth.gr
}

Received: February 3, 2015

Accepted: February 25, 2015

Available online: March 18, 2015

doi:10.11114/ijsss.v3i3.729

URL: http://dx.doi.org/10.11114/ijsss.v3i3.729

\begin{abstract}
Aim of this study: is a) to detect informal structures (power and position in structures of targeting of verbal aggression) among higher education students, b) to analyze determinants of these structural properties, and c) to propose a typology of verbal aggression targets. Complete network analysis was applied on a sample of a 53 students in Physical Education Faculty, Thessaly University, Greece. Four network analysis algorithms were used: in-degree, Katz status, pagerank, authority. Non-network and network determinants of being target of verbal aggressiveness were analyzed. Gender (particularly femaleness), high grade of school graduation and parents education level protect from verbal aggressiveness while interest in post-graduate study seems to provoke criticism. Ignoring public opinion and intimacy with many "close friends" are positively correlated with verbal aggressiveness. Young (and not old-fashioned) appearance, imposing and eccentric appearance characteristics seem to protect against verbal aggressiveness. Big corporal size, dark skin colors seem to provoke insults in case of female students. Eminent economic state is also provocative as it implies pretentiousness. Phone verbal aggressiveness appears mainly among male students. Eminent qualities such as "good friend", "desirable partner" etc make someone an eminent target for verbal aggressiveness. Verbal aggressiveness presents a catholic character and thus seems to be destructive and not constructive. Intellectual abilities (weaknesses) constitute a verbal aggressiveness target core. The following types of verbal aggressiveness targets are proposed: a) the "general "black sheep", b) the "contemptible type", c) the "bagger" type, d) the "victim of mockers" and e) the "victim of serial criticizers".
\end{abstract}

Keywords: verbal aggressiveness, insult, irony, mockery/cheating, students, network analysis, typology.

\section{Introduction}

It is well-known that the communication between people could be expressed with aggressive traits. A behavior may be considered as aggressive when someone implements symbolic and/or physical force aiming at being enforced or at harming another person, or even at defeating or destroying him (Infante, 1987). On the basis on Costa and MacRae (1980) study, Infante (1987) supported that verbal aggressiveness and argumentativeness are two communication traits (additionally to assertiveness and hostility) suggesting the main core of what is regarded as aggressive behavior. Nevertheless, the effects of argumentativeness still present an open issue for further research, especially in interaction with aggressiveness. Additionally, the question about the protective role of arguing and defining "important" information against verbal aggressiveness is worth exploring.

Verbally aggressive persons perceive their behavior as "fair" or necessary (Infante, Myers \& Buerkel, 1994). High verbally aggressive persons are unable to avoid the use of aggressive messages and they use them independent of who the conversation partner is (Valencic, Beatty, Rudd, Dobos \& Heisel, 1998).

Infante et al. (1994) suggested six important factors which are supposed to cause verbal aggressiveness: exploitation, reprimand, teasing, anger, self-defense as well as low capability of argumentation. At least the last dimension (argumentativeness, particularly criticism on positions rather than on self-perception) is emphasized as a protective means against verbal aggressiveness.

Verbal aggressiveness is inter alia expressed through various forms such as character- and competence-related attacks, attacks on physical appearance, ridicule, swearing and teasing (Infante \& Rancer, 1996). These forms of aggressiveness are expected to enhance development of informal hierarchies among the students. Moreover, a social milieu or a background which are considered to be an occasion for regarding someone as a target of aggression and for establishing 
such hierarchies.

The findings of several researches disclose the implications of verbal aggressiveness between parents and children (Martin \& Anderson 1997; Beatty, Zelley, Dobos, \& Rudd, 1994), among siblings (Martin, Anderson \& Rocca, 2005; Martin, Anderson, Burant \& Weber, 1997), between superiors and subordinates (Infante \& Gorden, 1991) as well as in marital relations. In the latter case, verbal aggressiveness is probable to lead up even to physical violence (Sabourin, Infante, \& Rudd, 1993, Infante \& Rancer, 1996). The education system still presents a serious research challenge, as it is supposed to be a subsystem of crucial importance for the everyday life and for the future career of the participants, who are involved formally or informally compulsorily.

Concerning education system, it has been supported that verbal aggression demotivates the children (Gorham \& Christophel, 1992) as it affects social attraction (Martin, Heizel \& Valencic, 1999; Rocca \& McCroskey, 1999). Furthermore, Myers and Knox (2000) supported that the verbal aggression of the instructors negatively influences the relation between instructor and student, affecting also the emotional learning and the students' satisfaction. Communication between teachers and students tends to affect learning, behaviour, thinking and motivation (Richmond \& Gorham, 1996; Bekiari, 2014). Rocca (2004) has also suggested that teachers' verbal aggressiveness has impacts even on the participation and the attendance of students. Motivation is also negatively influenced by the perception of certain messages of verbal aggression. These are supposed to be attacks on character, ridicule, competence, malediction, background, threats as well as nonverbal symbols (Myers \& Rocca, 2000). Furthermore, Myers and Rocca (2001) suggested that verbal aggressiveness is negatively correlated with the motivation and the perception of climate in the classroom. The verbal aggressiveness of instructors appears to have also negative impact on the students' affect toward the course content, the teacher and the recommended course behaviors (Myers \& Knox, 1999; Wrench \& Richmond, 2004). Also in the case of the academic advisors, the verbal aggressiveness seems to be negatively correlated with the advisors' credibility and advisees' affect (Wrench \& Punyanunt-Carter, 2005). The perceived verbal aggressiveness of the instructor appears also to restrict understanding and credibility, affecting simultaneously the students' motivation and willingness to communicate (Schrodt, 2003; Edwards \& Myers, 2007).

According to Bekiari, Kokaridas and Sakellariou (2005), students who consider that their physical education teachers are verbally aggressive present a tendency to learning loss. Also, Bekiari (2012) argues that teachers who are perceived as verbal aggressive make a negative impact on students' affect toward course, course-related behavior as well as the satisfaction in physical education. In a similar context, it has been supported that teachers' verbal aggression induces antisocial fair play behaviors while prosocial fair play behaviors are restricted by the verbal aggression of teachers (Hassandra, Bekiari, \& Sakellariou, 2007). Finally, Bekiari, Kokaridas and Sakellariou, (2006) mentioned that teachers' verbal aggression has a negative effect on the students' satisfaction as well as on certain motivation factors such enjoyment and interest, effort/importance and competence. The verbal aggression of teachers also affect discipline factors related to intrinsic and caring reasons.

The studies carried out until now have almost exclusively focused on aggressive relationships between instructors and addressees (children, pupils or higher education students and trainees). Koss, Gidycz, and Wisniewski (1987) have produced interesting results on aggressive relations between higher education students. However, they focused on the extreme case of sexual offensiveness. Scheithauer, Hayer, Petermann, and Jugert (2006) have suggested determinants (such as gender and age) of verbal and other forms of aggressiveness, but they have examined students of secondary school and not students of higher education.

Power theory seems to be of crucial importance for understanding verbal aggressiveness. Whether a powerful or a powerless actor (e.g. a student among many other students) tends to become a target of verbal aggressiveness is a serious research question. Whether the type of power (e.g. trust or threat) influences the tendency to become a target of verbal aggressiveness is also an interesting research question.

Popitz (1992) has proposed a functional and compact power model which seems to be applicable in any incidence of social life: a) action power (physical violence, depriving resources or isolation), b) instrumental power (threatened but not implemented action power), c) authoritative power (trust or emotional dependence), and d) data-setting power (imposing a situation by using material means, e.g. to establish a wall or a road in order to lead people to certain place, to separate female from male shower by wall or curtain etc). In our research, authoritative and instrumental power (trust and exchange, respectively) are examined as two power types which are often implemented among higher education students and are extensively detectable according to the everyday experience.

Additionally, behavior induced by powerlessness state (e.g. offering help without expecting any specific return) is also examined. Powerlessness can be attributed to anticipation even of possible compunction (emotional dependence) or to the anxiety of possible unwillingness of others to help him in a future situation (absolute instrumental power of others on him). Moreover, behavior of absolute independence (no helping at all) is examined as well. This absolute independence can be 
a result of complete emotional invulnerability or strong of autonomy and subsequent independence of any possible help in future. Thus, such a behavior constitutes an immunity to emotional dependence (dimension of authoritative power) or to incentive dependence (dimension of instrumental power).

No offering help at all (depriving resources) can be perceived as a result of generalized disappointment or as a long-range management of power (e.g. one may offer no help at all in order to create accumulated needs to the others and to gain their dependence more strongly). Offering help unconditionally (without expecting any specific return) can be attributed to absolute emotional dependence (one offers help in any case in order to avoid compunction or negative feelings derived from the fact that he did not help his fellows) or to anxiety that one will not receive any help in the future, if he does not steadily offer incentives.

These general notions of powerlessness and absolute dependence have been explored at such an abstract level for purpose of demarcation from the other two particular forms of power (trust and incentive dependence). Purpose of this research was not the further specification of this powerlessness and absolute dependence.

The method of Social Network Analysis enables an integration of verbal aggression and power relations. Xie, Farmer and Cairns (2003) have proposed substantial empirical findings about school children. They have implemented quantitative social network analysis on four types of aggression (verbal aggression, physical violence, two-person conflict and social exclusion). They suggested a gender-based typology of this four-dimension model. Mouttapa, Valente, Gallaher, Rohrbach and Unger (2004) have also conducted network analysis focusing on social-psychologist approaches (Dominance Theory and Social Cognitive Theory). They suggested not only a gender- but also an ethnicity-based typology of aggressive relations, exploring centrality in school networks.

However, a complete network analysis based on differentiated algorithms, subtle forms of verbal aggression and types of power relations (social structures such as trust or instrumental power), which appear among higher education students in their everyday life in and outside the campus, still remains an open research topic. Moreover, the statistical examination of correlation between network-variables as well as between network- and non network-variables is also an open research question.

Older papers have insightfully analyzed issues related to verbal communication (Brent, Thompson \& Mirielli, 1995), behavior control (Wiggins \& Heise, 1987; Smith-Lovin, 1987) or aggressiveness (Buontempo, Potrykus \& Kaufman, 2006). However, they did not focus specifically on verbal aggressiveness through detailed complete social network analysis.

1.1 Aim

Aim of this study: is a) to detect informal hierarchies (power structures and position in structures of targeting of verbal aggression) among higher education students, b) to analyze determinants of these structural properties, and c) to propose a typology of verbal aggression targets.

The expected practical added value lies in pointing out what makes a student target of verbal aggression and, thus, what can be a protective means against verbal aggressive action. These results can be practically useful for purpose of image-making or harmonic socializing. Apart from that, it could be useful not only for students but also for faculty staff to be aware of the fact that informal hierarchies of verbal aggression targeting (vs. reputation) exist among students. Thus, there are certain determinants which make out the respectable interlocutor or group leader in academic issues or in research projects.

Academic innovation is also intended, as:

a) the power model of Poppitz (1992), particularly trust and instrumental power structures (social structure analysis), and analysis of detailed forms of verbal aggressiveness (as psychological-pedagogical issue) are incorporated in each other (theoretical added value), and

b) different algorithms of network analysis (in-degree, Katz status, pagerank, authority) proved to be useful both for revealing different network properties as well as for understanding subtly differentiated social situations and structures (methodical added value).

\section{Method}

The method of complete network analysis focuses on actor interactions. These may be exchange of information and power relations (Skvoretz \& Willer, 1993; Cook \& Emerson, 1978; Jordan \& Schubert, 1992; Evans, 2001). We operationalized the basic power forms, namely trust and incentive (offering help). If a student gains the trust of his peers, then he can (mis)lead them (e.g. by advising them in scientific issues) (Vogt, 1997; Etzioni, 1975; Bachrach \& Baratz, 1962). When a student offers help under conditions (namely by agreeing a specific return), then he can instrumentalize the receivers who depend on his help. Actually, he gains their dependence by providing incentives (Pfeffer \& Salancik, 
1978).

We have also measured the cases in which no offering of incentives takes place at all as well as the cases in which offering help takes place unconditionally (without expecting any specific return).

A network of $\mathrm{n}$ students can visually be depicted as a polygon ( $\mathrm{n}$-gon), where the $\mathrm{n}$ nodes represent the students and the linking diagonals represent their relations (e.g. A trusts B, or A depends on the help of B, C and D). The network can be described as a matrix where the students are placed in the same order on both the vertical and horizontal axes. The elements of this matrix are the values of the relation from the vertical to horizontal axis (e.g. from A to B: no trust=0, trust=1). In this way, the network becomes algebraically processible. Trust and help dependence are measured here by our actors' responses to specific standardized questions. While the polygon is useful as an illustration, the matrix can be algebraically processed and analyzed. A matrix of 53 actors, for instance, consists of $53 \times 53-53=2756$ of possible diagonal interactions. Each one corresponds to a potential relation. A diagonal (relation) element exists when the value of the respective element differs from 0 . The length of a chain of successive trust relations (A trusts B, B trusts $\mathrm{C}$ and $\mathrm{C}$ trusts D) is used to define the trust "status" of actor D in the network. In this example, the actor D who has the highest trust status can influence actors C, B and A, by advising only C. The "status" formula of Katz (1953) is employed here.

The following network analysis algorithms have been used, which are measured by Visone software in normalized form (\%). Their meaning (social interpretation) is here described without presenting any formulas (these are complicated and easily accessible in various websites).

I) in-degree (occasional hierarchy position)

It is calculated as percentage of diagonal interactions received by a certain node. This algorithm can be interpreted as an occasional property (e.g. influence or aggression target). It is acquired by the interaction with all nodes with one has an immediate relation (e.g. gaining trust or receiving aggression).

II) status (accumulative hierarchy position)

Status is here calculated as a power series (Katz, 1953). It measures the chains of diagonal relations (successive links) concentrated by a node. E.g. if A trusts B, B trusts C and C trusts D, then D presents the highest status, as he can influence C, B and A by only one statement. Similarly, if A insults B, B insults C and C insults D, then D presents the highest status in aggression targeting, as he becomes the least reputable node in the network.

In any case, status expresses a property acquired by an accumulative procedure which subsequently establishes a deeper hierarchy and not an occasional (superficial) position such as in-degree). However, it is disadvantageous in comparison to in-degree, because it does not present clearly how many are the links though which a node may achieve (or receive) an immediate impact.

III) pagerank (distributive hierarchy position)

It is based on the transferred value (e.g. trusting) or depreciation (e.g. insulting or mockery) from one node to others. Successively, this value or depreciation is accumulated again to a final node of a chain. Thus, a pagerank property is quite similar to this of Katz status. However, pagerank yields more subtly differentiated values (numbers) between the nodes. Apart from that, it avoids certain calculated deformations caused by Katz status in case that a summit node with only one link to a subordinated node appears.

However, in contrast to status, pagerank does not yield 0-value (even final subordinated nodes have a pagerank value higher than 0). Independent of how "reality-close" this can be considered to be (matter of interpretation), it slightly influences the statistical processing of other calculations). Moreover, pagerank does not exactly expresses the depth of the established hierarchy of relational chains but rather the distributional structure of the relations (valuation or depreciation).

IV) authority (qualified competitiveness)

This algorithm points out someone with whom many other nodes want to maintain direct links (valuation or depreciation). In so far, it seems to a meaning similar to this of in-degree. However, it has a main difference: It does not plainly express how many givers (of trust or insult) intend to maintain direct contact to someone (receiver) but how many other receivers these givers have.

In other words, high authority characterizes someone who has attracted links of many other nodes who intensively are looking for something specific. Thus, they are not simply the first "occasional" givers as in the case of in-degree. Subsequently, a node who presents high authority (gaining trust) in advising (e.g. about Natural Science issues) has dominated among those who tend to play the advisors. Thus, it could be characterized as specifically qualified competitor in this subject.

Similarly, someone who attracts the greatest share of insults from systematic insulters, then he seems to be a good receiver 
for everyone that tends to insult others and functions socially as an attractive "punching bag".

It is noticed that the use of the Eigenvector algorithm has been avoided, because it yields outliers, in contrast to status and pagerank, which produces more subtle stratification.

\subsection{Sample}

Network ("snowball") sampling has been conducted in a class of 53 students ( $4^{\text {th }}$ semester) from Physical Education Faculty of the University of Thessaly (Trikala) in Mai 2014. The sample consisted of 31 male and 22 female, aged from 20 to $46(\mathrm{M}=21, \mathrm{SD}=3.69)$. The participants came from various regions of Greece and belonged to different socio-economic status.

All students were familiar with each other and have answered a standardized questionnaire about various relations developed among them. The questionnaires should be named, because otherwise a complete network analysis would technically infeasible. However, it was emphasized to them that their names would be known only to the researcher. In this way, sincere information was expected to be received.

A network is by definition not a random sample. However, this is not considered to be a weakness, as purpose of this research was not the descriptive statistics (generalization of any descriptive quantitative property) but the analytical statistics (correlations).

\subsection{Questionnaire}

The questionnaire was based on the Verbal Aggressiveness Scale (VAS; Infante \& Wigley, 1986) that was adapted to Greek population by Bekiari et al. (2006) was used, in order to measure verbal aggressiveness as perceived by Physical Education students.

The questionnaire consisted of two parts: a) non-network variables (e.g. gender, birth year etc), and b) network variables. Concerning part $b$, additional questions were added to the questionnaire of Infante and Rancer (1986) about trust (advising about study issues, particularly Humanities and Natural Sciences), incentives (offering help), socialization patterns (companion within and outside faculty) and study and general cooperation. We have also differentiated the verbal aggressiveness depending on the field (behavior, appearance, intellectual abilities, background/social milieu) and on the style (ironic/mockery or serious style).

\subsection{Process and statistical analysis}

The nodes of the network were 53 students known to the researcher. They were completely accessible in a compulsory laboratory class. The questionnaires were distributed to them and returned during the lesson. Thus, the response was $100 \%$. It was certified to them that the questionnaires will be handled with discretion and the names will be known only to the researcher. It was also explained that each one could be informed his network position after the analysis but only with a personal code number known only to him. In this way, sincerity was assured. The completion of questionnaires lasted for 20-30 minutes approximately and flowed freely. Furthermore, student participation in the process was voluntary, while those who did not wish to take part did not have to do so. Before completing the questionnaires, participants signed a consent form. The study was conducted in accordance to the best practice, ethics, and code of conduct.

The network data were processed by Visone 1.1 software. Afterwards, both non-network and network variables were entered in SPSS 15. After normality control with Kolmogorov-Smorinov and Shapiro-Wilk, bivariate correlation Spearman was applied. The interpretation was focused on statistically significant coefficients $(* *: p \leq 0.05$ and $*: p \leq 0.01)$. The bivariate analysis was preferred to multivariate analysis because it reveals many more correlations among variables. Multivariate analysis is more appropriate for examining fewer and more specific variables.

The interpretation of the results has been based on in-depth interviews.

\section{Results and Discussion}

In the figures 1-6 the networks of verbal aggressiveness are depicted: The network of criticism on 1) intellectual abilities, 2) behavior, 3) appearance, 4) background and/or social milieu, and 5) ironic comments as well as 6) cheating. The distinctive number of each node is not visible. However, this is not necessary. It is enough that the two different colors (blue $=$ male, red=female students) can be distinguished (even in a white-black version they are distinguishable in grey-scale). Thus, the first noticeable result is that not always the same node is the top target of verbal aggression. For example, in case of criticism on background/ social milieu (figure 4) the top target in Katz status and pagerank is a male student while he is replaced by a female student in authority, in pagerank of irony a group of 5-6 male students is distinguished as a top target, in authority hierarchy of cheating a male and a female student possess the two top target positions. For such a quasi-qualitative diagnosis of social structures such a visualization of network is useful. 


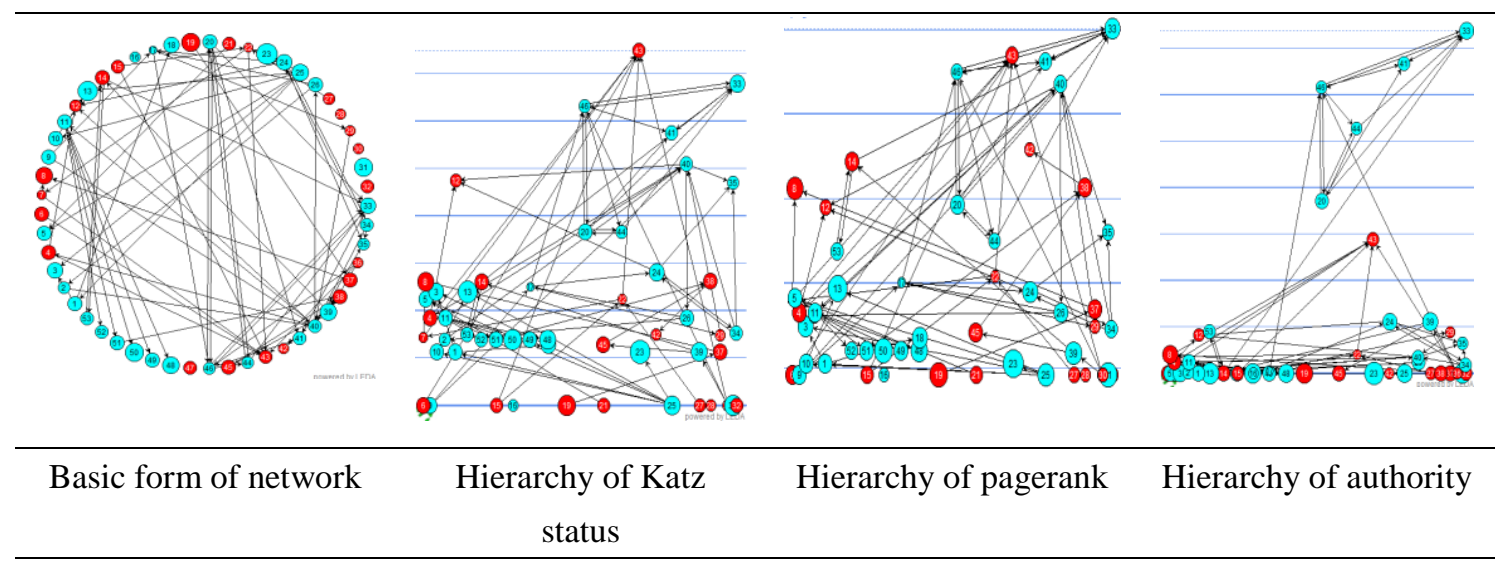

Targeting for negative comments about intellectual abilities, nodes $=53$, links $=70$

$\left[\right.$ density $\left.=70 /\left(53^{2}-53\right)=2.5 \%\right]$

Figure 1. Network of verbal aggressiveness (criticism on intellectual abilities)

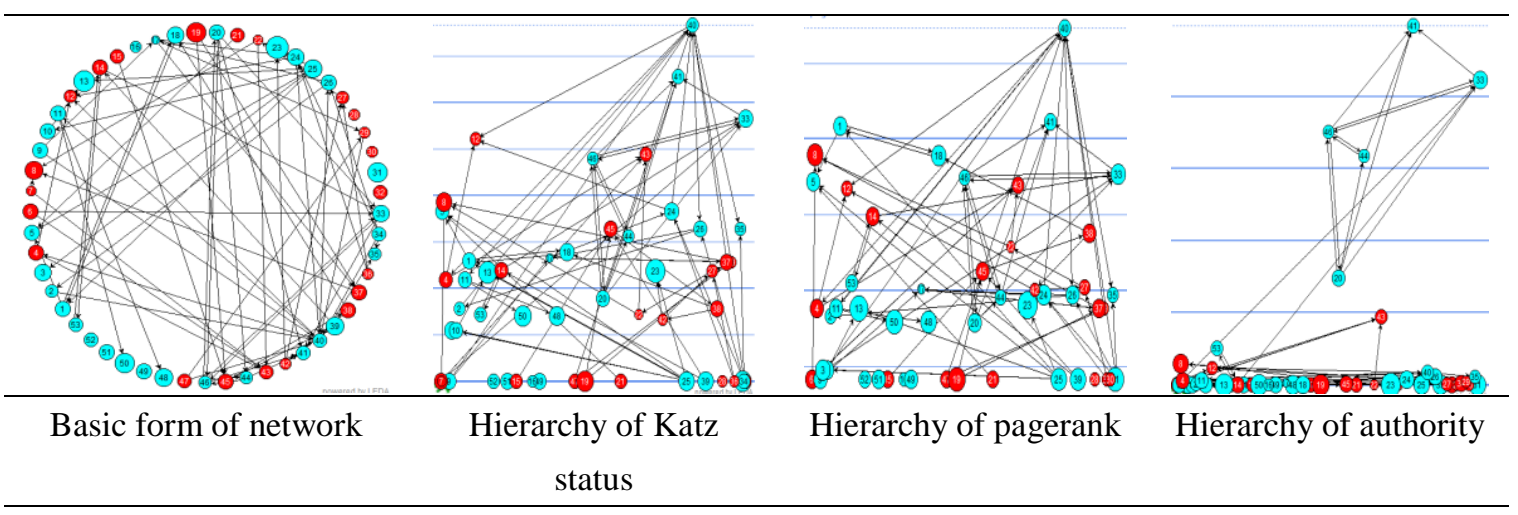

Targeting for negative comments about behavior, nodes $=53$, links $=72$

[density $=72 /\left(53^{2}-53\right)=2.6 \%$ ]

Figure 2. Network of verbal aggressiveness (criticism on behavior)
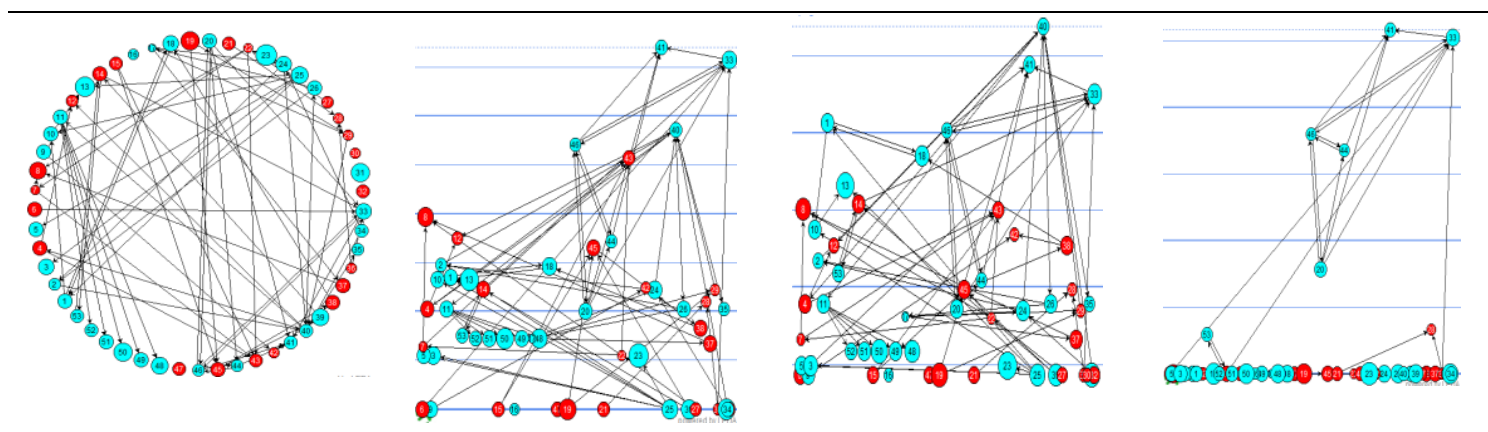

Basic form of network

Hierarchy of Katz

Hierarchy of pagerank

Hierarchy of authority

status 
Targeting for negative comments about appearance, nodes $=53$, links $=69$

$\left[\right.$ density $\left.=69 /\left(53^{2}-53\right)=2.5 \%\right]$

Figure 3. Network of verbal aggressiveness (criticism on appearance)
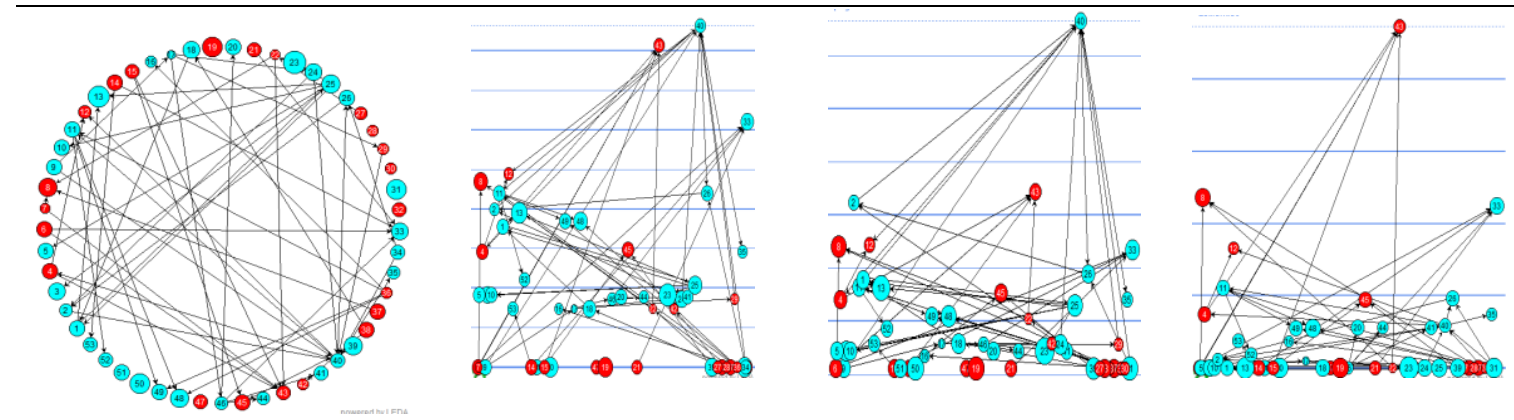

Basic form of network

Hierarchy of Katz

Hierarchy of pagerank

Hierarchy of authority status

Targeting for negative comments about background or social milieu, nodes $=53$, links $=55$

$\left[\right.$ density $\left.=69 /\left(53^{2}-53\right)=1.9 \%\right]$

Figure 4. Network of verbal aggressiveness (criticism on background or social milieu)

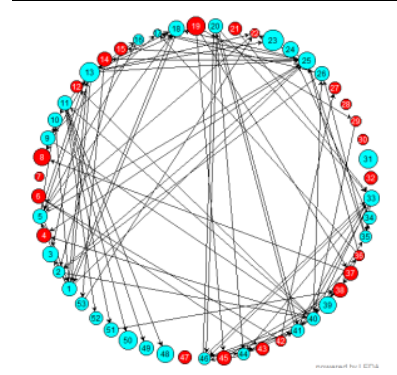

Basic form of network

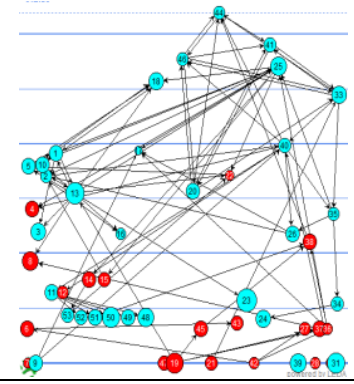

Hierarchy of Katz

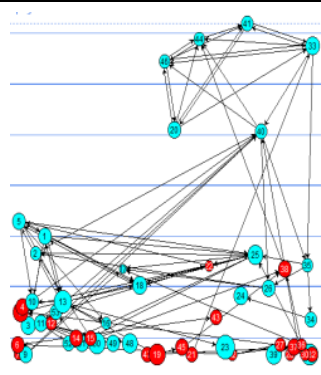

Hierarchy of pagerank

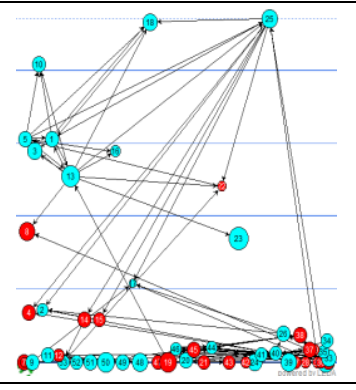

Hierarchy of authority status

Targeting for ironic comments, nodes $=53$, links $=89,\left[\right.$ density $\left.=89 /\left(53^{2}-53\right)=3.2 \%\right]$

Figure 5. Network of verbal aggressiveness (irony) 


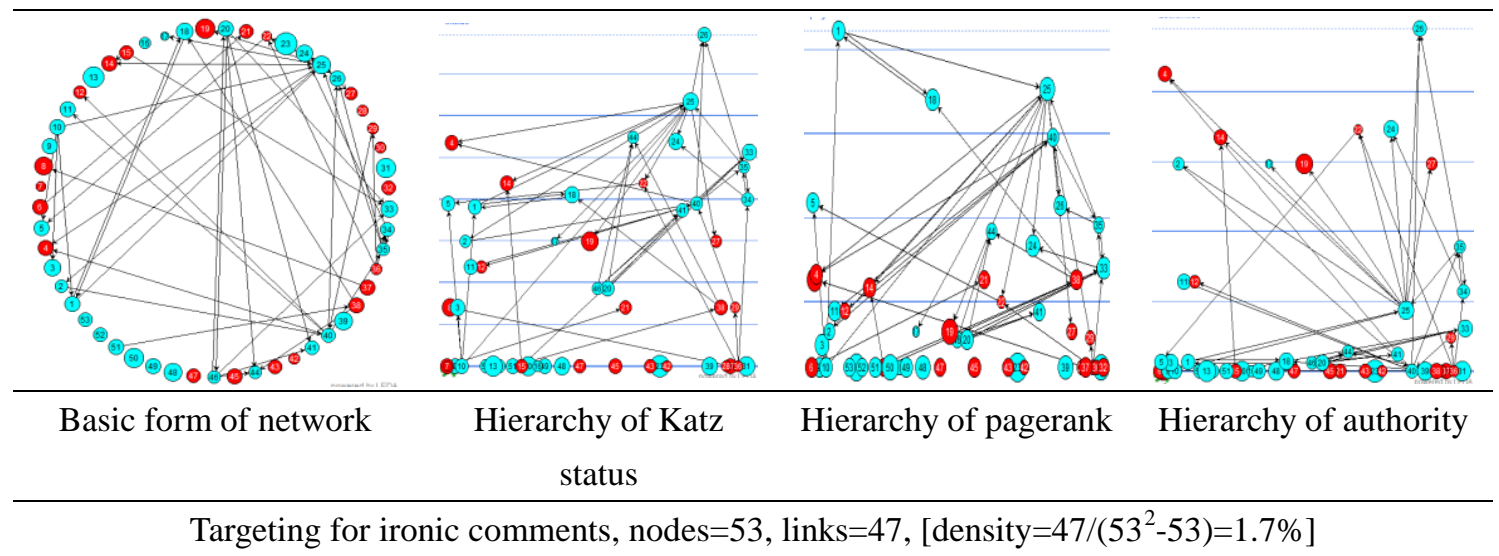

Figure 6. Network of verbal aggressiveness (cheating)

The basic form is indicative of the density (percentage of existent relations to the whole possible relations) of each network. The least dense networks are $2(1.9 \%)$ and $6(1.7 \%)$ while the most dense is $5(3.2 \%)$. This is understandable as exerting criticism on background or social milieu of someone necessitates access to very specific personal information which is normally discrete and not widely known. Cheating is also not widely practiced but rather focused on specific persons. It necessitates also access to specific information about weaknesses of someone and often is connected with satisfaction of personal interests. On the contrary, irony is widely and easily practiced in conflicting relations for disdaining as well as in friendly relations for fun.

Concerning the hierarchies (status, pagerank and authority), the higher the layer of a person (node) is, the more susceptible he/she is to receive negative comments, irony or cheating and thereby to become target of verbal aggression. In-degree is not presented as it is not visualized by Visone as pyramid but only numerically calculated.

\subsection{Verbal Aggressiveness and Individual Parameters}

Table 1. Verbal Aggressiveness Target (Serious Style) and Social-Personal Parameters (whole sample)

\begin{tabular}{|c|c|c|c|c|c|c|c|}
\hline & $\begin{array}{l}\text { criticism } \\
\text { on } \\
\text { intellectu } \\
\text { al } \\
\text { abilities } \\
\text { (pageran } \\
\text { k) }\end{array}$ & $\begin{array}{c}\text { criticism on } \\
\text { behavior } \\
\text { (pagerank) }\end{array}$ & $\begin{array}{l}\text { criticism on } \\
\text { appearance } \\
\text { (authority) }\end{array}$ & $\begin{array}{c}\text { criticism on } \\
\text { social } \\
\text { milieu-backg } \\
\text { round } \\
\text { (in-degree) } \\
\end{array}$ & $\begin{array}{l}\text { criticism on } \\
\text { social } \\
\text { milieu-backgro } \\
\text { und (status) }\end{array}$ & $\begin{array}{l}\text { criticism on } \\
\text { social } \\
\text { milieu-backg } \\
\text { round } \\
\text { (pagerank) }\end{array}$ & $\begin{array}{l}\text { criticism on } \\
\text { social } \\
\text { milieu-backgr } \\
\text { ound } \\
\text { (authority) }\end{array}$ \\
\hline $\begin{array}{c}\text { gender } \\
(\text { male }=0, \text { female }=1)\end{array}$ & .429 & .583 & .110 & .018 & .013 & .058 & .039 \\
\hline \multirow[t]{2}{*}{ birth year } & -.003 & .176 & $-.338(*)$ & .179 & .205 & .226 & .126 \\
\hline & .984 & .216 & .015 & .208 & .150 & .111 & .377 \\
\hline \multirow[t]{2}{*}{ school graduation grade } & -.113 & -.098 & -.089 & $-.373(* *)$ & $-.374(* *)$ & $-.396(* *)$ & $-.350(*)$ \\
\hline & .441 & .502 & .544 & .008 & .008 & .005 & .014 \\
\hline \multirow[t]{2}{*}{$\begin{array}{l}\text { interested in being } \\
\text { appreciatied by the others }\end{array}$} & -.070 & -.219 & -.047 & $-.284(*)$ & $-.294(*)$ & -.268 & -.261 \\
\hline & .628 & .122 & .742 & .043 & .036 & .057 & .064 \\
\hline \multirow[t]{2}{*}{$\begin{array}{c}\text { how many «close friends» } \\
\text { you have }\end{array}$} & $.299(*)$ & .160 & .075 & .144 & .058 & .164 & -.075 \\
\hline & .037 & .273 & .607 & .323 & .692 & .259 & 609 \\
\hline
\end{tabular}

** Correlation is significant at the 0.01 level (2-tailed).

* Correlation is significant at the 0.05 level (2-tailed).

In table 1 it is noticeable that the female students are not susceptible to be verbally assaulted concerning their social milieu or background $(-.331,-.346,-.290)$. This is understandable, considering that such a criticism would be quite extreme for female students. Thus, normally it is a ground for critical discussion in acceptable framework only among 
male students.

The young students are not criticized (-.338) because of their appearance. Only older students present tendency to be criticized about that. This can be attributed to the fact that persons who have decided to become students again at high age are distinguished in a milieu of much younger people because they have permanently adopted a more serious dressing style from this of much younger students who still are dressed as teenagers (ruptured jeans, T-shirts, shorts etc).

Students who graduated from school with high grade are considered to maintain an acceptable milieu or to have built a sound background. Thus, they are difficult to become target of criticism about this (-.373 to -.396).

Those who are criticized about their intellectual abilities (.283) as well as about their behavior (.279) tend to ignore the opinion of the others about themselves as a reaction of self-protection. Those who are not interested $(-.284,-.294)$ in gaining the appreciation tend to attract criticism about their social milieu or background. This is understandable considering the fact the persons who present such an independence of the public opinion as a rule have a tendency of isolationism which seems to be provocative to some other students.

Students who consider relatively large groups as their "close company" and subsequently they tend to develop quickly familiarity feeling and intimate discussion with many students offer simultaneously many occasions for criticism about their intellectual abilities (.299). This means that they are tried in argumentative live-"chats" and, consequently their weaknesses are revealed.

Table 2. Verbal Aggressiveness Target (Serious Style) And Appearance Parameters (whole sample)

\begin{tabular}{|c|c|c|c|c|c|c|c|}
\hline & $\begin{array}{c}\text { criticism on } \\
\text { intellectual } \\
\text { abilities } \\
\text { (in-degree) }\end{array}$ & $\begin{array}{c}\text { criticism on } \\
\text { intellectual } \\
\text { abilities } \\
\text { (authority) } \\
\end{array}$ & $\begin{array}{l}\text { criticism on } \\
\text { appearance } \\
\text { (authority) }\end{array}$ & $\begin{array}{c}\text { criticism } \\
\text { on social } \\
\text { milieu-ba } \\
\text { ckground } \\
\text { (in-degre } \\
\text { e) }\end{array}$ & $\begin{array}{l}\text { criticism } \\
\text { on social } \\
\text { milieu-ba } \\
\text { ckground } \\
\text { (status) }\end{array}$ & $\begin{array}{c}\text { criticism on } \\
\text { social } \\
\text { milieu-backgr } \\
\text { ound } \\
\text { (pagerank) }\end{array}$ & $\begin{array}{c}\text { criticism on } \\
\text { social } \\
\text { milieu-backg } \\
\text { round } \\
\text { (authority) }\end{array}$ \\
\hline \multirow[t]{2}{*}{ hair very long } & -.124 & -.078 & -.142 & $-.288(*)$ & $-.293(*)$ & -.213 & $-.288(*)$ \\
\hline & .385 & .588 & .321 & .040 & .037 & .133 & .040 \\
\hline \multirow[t]{2}{*}{$\begin{array}{c}\text { eccentric } \\
\text { appearance }\end{array}$} & -.152 & $-.302(*)$ & -.145 & -.048 & -.049 & -.091 & -.051 \\
\hline & .287 & .031 & .310 & .737 & .733 & .524 & .724 \\
\hline \multirow[t]{2}{*}{ height } & .246 & .009 & .159 & $.309(*)$ & $.312(*)$ & .231 & .171 \\
\hline & .081 & .951 & .264 & .027 & .026 & .103 & .229 \\
\hline \multirow[t]{2}{*}{ weight } & .243 & .150 & $.314(*)$ & $.381(* *)$ & $.374(* *)$ & $.310(*)$ & .273 \\
\hline & .085 & .292 & .025 & .006 & .007 & .027 & .053 \\
\hline
\end{tabular}

** Correlation is significant at the 0.01 level (2-tailed).

* Correlation is significant at the 0.05 level (2-tailed).

In the table 2, certain appearance characteristics seem also to be determinants of being target of verbal aggressiveness. Maintaining very long hairs can reasonably be regarded to be a basis of more imposing appearance (this concerns only female students in this sample). Such an appearance discourages any attempt to criticize the milieu or the background of someone $(-.288,-.293,-.288)$.

Students who appear as eccentric (-.302) achieve to discourage criticism concerning their intellectual abilities while their eccentricity seem not to attract any other verbal assault (insign. coefficients). This result can be attributed to the fact that eccentricity enhances an imposing appearance.

The height $(.309, .312)$ as well as the weight $(.314$ to .381$)$ seems to draw attention and to trigger negative comments regarding appearance or social milieu and background. As far as height is concerned, this negative impact can be understood as a result of the jealousness, presuming that being tall often assures an imposing appearance. Especially in a Physical Education department the tallness is regarded as an advantage for a sport career. Regarding weight, it is a disadvantage for the appearance and to certain extent also for the sport career. Thereby, it makes someone more vulnerable and susceptible to be criticized for his appearance and subsequently also for other reasons (e.g. social milieu or background). Although such other reasons are completely irrelevant to the appearance, they make criticism more intensive. 
Table 3. Verbal Aggressiveness Target (serious style) and Appearance Parameters (Male Students)

\begin{tabular}{lc}
\hline & $\begin{array}{c}\text { criticism on appearance } \\
\text { (authority) }\end{array}$ \\
\hline olive or brown skin & $\mathbf{. 3 6 7}(*)$ \\
& $\mathbf{. 0 4 6}$ \\
heaviness (=weight/height) & $\mathbf{. 3 6 5}(*)$ \\
& $\mathbf{. 0 4 7}$ \\
\hline
\end{tabular}

** Correlation is significant at the 0.01 level (2-tailed).

* Correlation is significant at the 0.05 level (2-tailed).

Physical parameters such as skin color or heaviness (=weight/height) seem to affect their position in criticism about their appearance $(.367, .365$ in table 3$)$. Such characteristics appear to attract negative comments against male students as they imply a slight racism based on aesthetic criteria. While such a skin color is not negatively assessed in case of female students, in case of male ones it is considered to imply an origin from or immediate relation to non-mainstream cultures or marginal groups (e.g. gypsy). Heavy people are also to certain extent disadvantaged for a sport career.

\subsection{Correlations}

Table 4. Verbal aggressiveness target (serious style) and appearance parameters (female students)

\begin{tabular}{lccc}
\hline & $\begin{array}{c}\text { criticism on appearance } \\
\text { (in-degree) }\end{array}$ & $\begin{array}{c}\text { criticism on appearance } \\
\text { (status) }\end{array}$ & $\begin{array}{c}\text { criticism on appearance } \\
\text { (pagerank) }\end{array}$ \\
\hline hair blonde & $\mathbf{- . 4 5 7}(*)$ & $\mathbf{- . 4 5 1}(*)$ & $\mathbf{. 4 5 1}(*)$ \\
& $\mathbf{. 0 3 7}$ & $\mathbf{. 0 4 0}$ & $\mathbf{. 0 4 0}$ \\
hair black & .140 & .165 & $\mathbf{. 4 4 1}(*)$ \\
& .546 & .474 & $\mathbf{. 0 4 5}$ \\
\hline
\end{tabular}

** Correlation is significant at the 0.01 level (2-tailed).

* Correlation is significant at the 0.05 level (2-tailed).

In table 4 , it is observed that blonde female students $(-.457,-.451,-.451)$ are avoided as target for criticism about their appearance in contrast to those with black hair (.441). This empirical finding shows that blonde hair tends to be regarded as evidence of nobleness as a normative extension of eminent beautifulness.

Table 5. Verbal Aggressiveness Target (Ironical/ Cheating Style) and Social-Personal and Appearance Parameters

(Whole Sample)

\begin{tabular}{|c|c|c|c|c|c|c|c|c|c|}
\hline & & $\begin{array}{c}\text { irony } \\
\text { (in-degree) }\end{array}$ & $\begin{array}{c}\text { irony } \\
\text { (status) }\end{array}$ & $\begin{array}{c}\text { irony } \\
\text { (pagerank) }\end{array}$ & $\begin{array}{c}\text { irony } \\
\text { (authority) }\end{array}$ & $\begin{array}{c}\text { mockery/ } \\
\text { cheating } \\
\text { (in-degree) }\end{array}$ & $\begin{array}{l}\text { mockery } \\
\text { /cheating } \\
\text { (status) }\end{array}$ & $\begin{array}{l}\text { mockery/ } \\
\text { cheating } \\
\text { (pagerank) }\end{array}$ & $\begin{array}{c}\text { mockery/ } \\
\text { cheating } \\
\text { (authority) }\end{array}$ \\
\hline \multirow{9}{*}{ 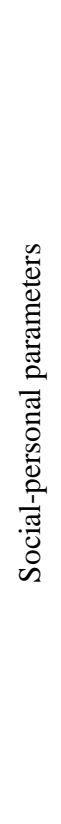 } & $\begin{array}{c}\text { gender } \\
\text { (male }=0 \text {,femal }\end{array}$ & $-.437(* *)$ & $-.501(* *)$ & $-.489(* *)$ & -.209 & -.209 & -.215 & -.197 & -.116 \\
\hline & & .001 & .000 & .000 & .141 & .140 & .130 & .165 & .418 \\
\hline & $\begin{array}{l}\text { mother } \\
\text { education }\end{array}$ & -.128 & -.181 & -.109 & -.158 & -.147 & -.182 & -.108 & $-.296(*)$ \\
\hline & & .382 & .214 & .455 & .278 & .315 & .210 & .461 & .039 \\
\hline & $\begin{array}{c}\text { school } \\
\text { graduation }\end{array}$ & $-.327(*)$ & $-.332(*)$ & $-.348(*)$ & -.099 & -.153 & -.193 & -.154 & -.178 \\
\hline & & .022 & .020 & .014 & .498 & .294 & .184 & .292 & .222 \\
\hline & $\begin{array}{c}\text { desire to } \\
\text { continue } \\
\text { postgraduate }\end{array}$ & .212 & .222 & .147 & $.344(*)$ & .076 & .033 & .089 & -.038 \\
\hline & & .153 & .134 & .326 & .018 & .612 & .828 & .551 & .799 \\
\hline & $\begin{array}{l}\text { month } \\
\text { expenses }\end{array}$ & .105 & .104 & .072 & .261 & $.293(*)$ & $.300(*)$ & $.298(*)$ & .284 \\
\hline
\end{tabular}




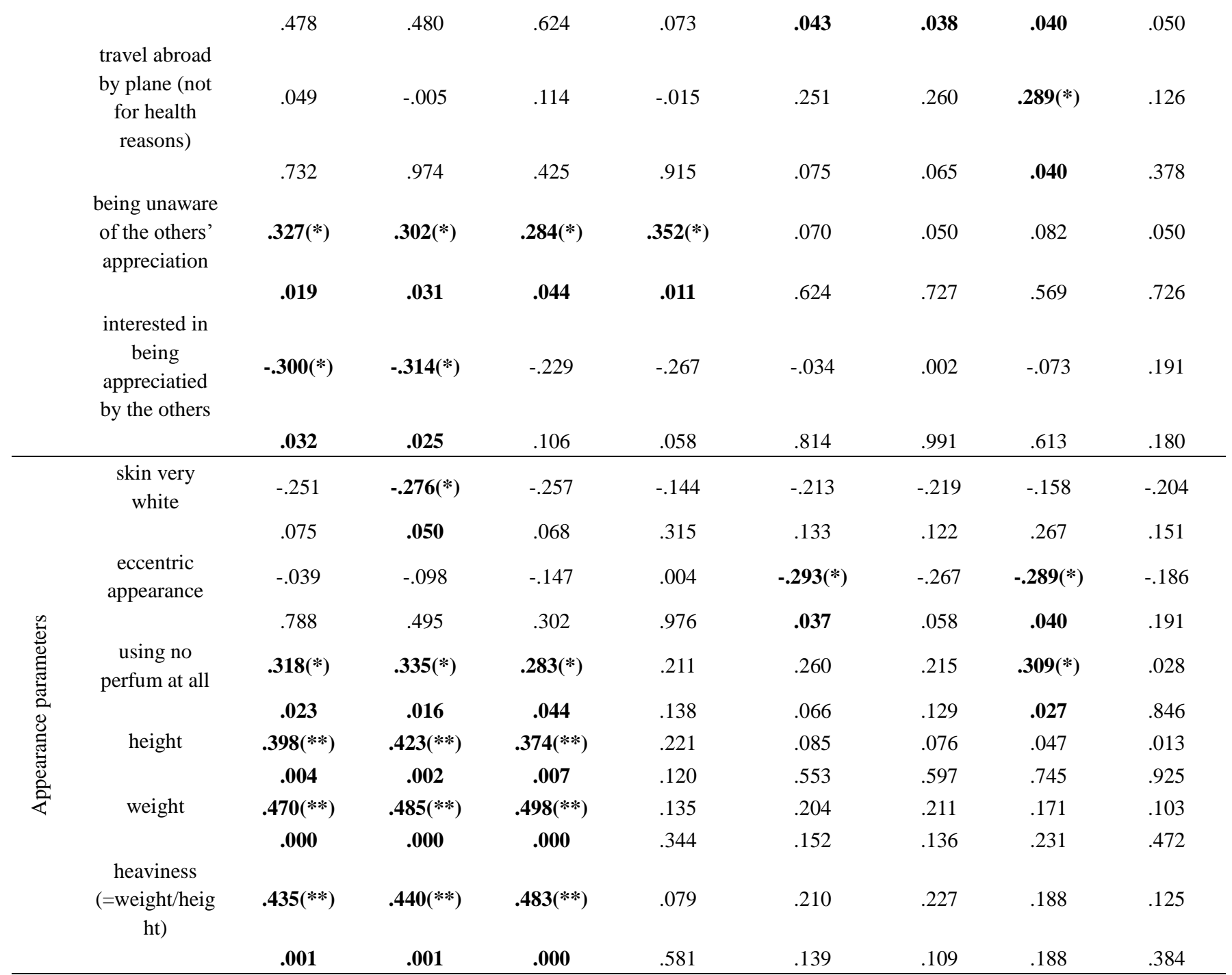

In table 5, numerous parameters appear to be related to verbal aggressiveness. Concerning social-personal characteristics, gender seems to be of importance for the verbal behavior. Male students appear to be more susceptible to be target of ironic verbal assaults (-.437 to -.501). This can reasonably be understood as a result of cloddishness or laddishness manner that male young people often use to express and impose themselves.

The mother education level appears to determine the pedagogical culture and subsequently the habitus and manner of the students. This is an explanation about why students originating from a family with a high-education-level mother tend to avoid people who like cheating or mockery. Thereby, they achieve not to become target of such verbal aggressiveness (-.296). Students graduated from school with high grade (-.327 to -.348) seem also to avoid being familiar to people who tend to make ironic comments, as they take their study and career seriously. In other words, they "respect themselves". However, those who are ambitious and intend to make postgraduate studies seem to attract more ironic comments (.344), as a result of being "snubbed" by the others.

Those who lead a wealthy life spending money (.293 to .300) or traveling abroad (.289) seem to attract mockery or cheating from the others. Wealthy students are often regarded by the others as pretentious and provocative. Thus, cheating or mockery can be perceived in this case as a reaction to this perceived (or real) pretentiousness.

A student who has become target of ironic comments avoids often contacts to others and thus he does not know the opinion of other students about himself $(.284$ to .352$)$ or even he is no more interested in their opinion at all $(-.300$, $-.314)$, as a reaction against verbal aggressiveness.

Regarding parameters of appearance, the very white skin seems to discourage ironic assaults (-.276), as it inspires feeling of nobleness like the blonde hair (s. also table 4). Eccentricity $(-.289,-.293)$ also plays a protective role against mockery and cheating, similar to this described in table 2 .

Moreover, the social influence that a perfume is expected to enhance becomes evident by the results of table 5. Students 
who do not use perfume at all tend to be target of more ironic comments (.283 to .335 ). Thus, using perfume seems to discourage disdain expressed through irony, as it inspires a feeling of nobleness and imposing appearance. However, tallness (.374 to .423), weight (.470 to .498) and heaviness (=weight/height) (.435 to .483 ) seem also to play in this table a negative social role similar to this examined and discussed in table 2 and 3, raising feeling of jealousness or disdain. Tallness is considered to be an enviable charisma for sport career while big weight and especially heaviness is regarded as a serious disadvantage in general and much more particularly in a Physical Education department, making someone attractive for ironic comments.

Table 6. Verbal Aggressiveness Target (Ironical/ Cheating Style) and Appearance Parameters (male students)

\begin{tabular}{lcccc}
\hline & $\begin{array}{c}\text { irony } \\
\text { (pagerank) }\end{array}$ & $\begin{array}{c}\text { irony } \\
\text { (authority) }\end{array}$ & $\begin{array}{c}\text { mockery/cheating } \\
\text { (in-degre) }\end{array}$ & $\begin{array}{c}\text { mockery/cheatin } \\
\text { g (authority) }\end{array}$ \\
\hline eccentric appearance & -.135 & .144 & $\mathbf{. 3 7 3}(*)$ & -.342 \\
& .476 & .448 & $\mathbf{. 0 4 3}$ & .065 \\
using smooth perfum & -.033 & $\mathbf{- . 3 6 2}(*)$ & -.079 & .170 \\
& .864 & $\mathbf{. 0 4 9}$ & .678 & .368 \\
Height & -.061 & .066 & -.203 & $\mathbf{- . 3 7 4}(*)$ \\
& .748 & .731 & .283 & $\mathbf{. 0 4 2}$ \\
Heaviness & $\mathbf{. 3 6 9}(*)$ & -.081 & .116 & -.062 \\
(=weight/height) & $\mathbf{. 0 4 5}$ & .672 & .541 & .743 \\
& & & & \\
\hline
\end{tabular}

** Correlation is significant at the 0.01 level (2-tailed).

* Correlation is significant at the 0.05 level (2-tailed).

Especially in male part of the sample (table 6) the eccentricity (-.373) and using smooth perfume (-.362) prove once again to function as protective means against mockery or cheating due to the imposing appearance and nobleness they induce (s. also above).

However, particularly in the case of male students the tallness (-.374) seems to be protective against mockery or cheating. In contrast to the results concerning the general sample presented above, tallness tends here to enhance the male imposing appearance rather than verbal aggressiveness due to jealousness.

Nevertheless, heaviness is still a negative factor attracting ironic comments even in case of the male students (.369).

Table 7. Verbal aggressiveness target (ironical/ cheating style) and appearance parameters (female students)

\begin{tabular}{|c|c|c|c|c|c|c|c|c|}
\hline & $\begin{array}{l}\text { irony } \\
\text { (in-degr } \\
\text { ee) }\end{array}$ & $\begin{array}{l}\text { irony } \\
\text { (status) }\end{array}$ & $\begin{array}{l}\text { irony } \\
\text { (pagera } \\
\text { nk) }\end{array}$ & $\begin{array}{l}\text { irony } \\
\text { (authori } \\
\text { ty) }\end{array}$ & $\begin{array}{c}\text { mocker } \\
\text { y/cheati } \\
\text { ng } \\
\text { (in-degr } \\
\text { ee) }\end{array}$ & $\begin{array}{c}\text { mockery } \\
\text { /cheatin } \\
\mathrm{g} \\
\text { (status) }\end{array}$ & $\begin{array}{l}\text { mockery/ } \\
\text { cheating } \\
\text { (pageran } \\
\text { k) }\end{array}$ & $\begin{array}{c}\text { mockery } \\
\text { /cheatin } \\
\mathrm{g} \\
\text { (authorit } \\
\text { y) }\end{array}$ \\
\hline \multirow[t]{2}{*}{ hair straight } & $-.546(*)$ & $-.512(*)$ & $-.525(*)$ & -.349 & $-.481(*)$ & $-.472(*)$ & $-.556(* *)$ & -.290 \\
\hline & .010 & .018 & .015 & .122 & .027 & .031 & .009 & .201 \\
\hline \multirow[t]{2}{*}{ hair curly } & .255 & .324 & .287 & .231 & $.547(*)$ & $.610(* *)$ & $.450(*)$ & $.656(* *)$ \\
\hline & .264 & .151 & .207 & .314 & .010 & .003 & .041 & .001 \\
\hline \multirow[t]{2}{*}{ hair tied } & $.584(* *)$ & $.673(* *)$ & $.720(* *)$ & $.499(*)$ & .212 & .161 & .283 & .000 \\
\hline & .005 & .001 & .000 & .021 & .357 & .487 & .215 & 1.000 \\
\hline
\end{tabular}

** Correlation is significant at the 0.01 level (2-tailed).

* Correlation is significant at the 0.05 level (2-tailed).

In the case of female students (table 7) the hair style seems to be a determinant of becoming a target of verbal aggressiveness. Students with straight hair seem to discourage irony (-.512 to -.546) or mockery (-.472 to -.556) against themselves. On the contrary, curly-haired students appear to attract mockery (.450 to .656) as their hair style is regarded as more distinct and provocative. Tied hair is also regarded as a distinct and provocative style, attracting irony (.499 to .720). In general, it is well known that the female hair style is considered to be a social influence tool attracting a considerable investment of time and money in hair styling salons. This is supported also by the afore-mentioned empirical results which show a strong reaction to the more sophisticated styling. 
Table 8. Verbal aggressiveness target (way/distance) and social-personal and appearance parameters (whole sample)

\begin{tabular}{|c|c|c|c|c|c|c|c|}
\hline & $\begin{array}{c}\text { insult with } \\
\text { email/sms/ } \\
\text { letter } \\
\text { (in-degree } \\
\text { ) }\end{array}$ & $\begin{array}{c}\text { insult with } \\
\text { email/sms/ } \\
\text { letter } \\
\text { (status) }\end{array}$ & $\begin{array}{c}\text { insult with } \\
\text { email/sms/ } \\
\text { letter } \\
\text { (pagerank) }\end{array}$ & $\begin{array}{l}\text { insult by } \\
\text { phone } \\
\text { (in-degree } \\
\text { ) }\end{array}$ & $\begin{array}{l}\text { insult by } \\
\text { phone } \\
\text { (status) }\end{array}$ & $\begin{array}{c}\text { insult by } \\
\text { phone } \\
\text { (pagerank) }\end{array}$ & $\begin{array}{c}\text { insult by } \\
\text { phone } \\
\text { (authority) }\end{array}$ \\
\hline \multirow[t]{2}{*}{$\begin{array}{c}\text { gender } \\
(\text { male }=0, \text { female }=1)\end{array}$} & -.165 & -.156 & -.185 & -.273 & $-.305(*)$ & -.271 & $-.363(* *)$ \\
\hline & .247 & .273 & .195 & .053 & .030 & .054 & .009 \\
\hline \multirow[t]{2}{*}{$\begin{array}{c}\text { Heaviness } \\
\text { (=weight/height) }\end{array}$} & $.352(*)$ & $.382(* *)$ & $.352(*)$ & $.329(*)$ & $.339(*)$ & $.336(*)$ & $.299(*)$ \\
\hline & .011 & .006 & .011 & .018 & .015 & .016 & .033 \\
\hline
\end{tabular}

** Correlation is significant at the 0.01 level (2-tailed).

* Correlation is significant at the 0.05 level (2-tailed).

Concerning the way of verbal aggressiveness (e.g. through sms/ email, by phone or face-to-face), a characteristic role of gender and physical appearance is evident in table 8 . The female students are susceptible to avoid verbal assault made by phone $(-.305,-.363)$ in contrast to the male students. This can be explained by the fact that male students mainly develop telephonic chats which include blustering or grumbling in a cloddish style ( $\mathrm{s}$. also above). On the contrary, it is well-known from the everyday experience that the female students normally develop by phone more detailed social criticism. This normally concerns third persons and is sometimes negatively characterized as "gossiping". In any case, it usually does not include aggressively contradictions between each other and is expected to be conducive to relaxation rather than to conflict. The male students prefer to use phone in order to release their indignation and intensity or pressure as this means is the safest one for this purpose.

The heaviness is a determinant which makes the telecommunication means (sms/email and phone) more preferable for releasing verbal aggressiveness (.299 to .382). This is evidence that heavy discussants have a more imposing appearance, implying that verbal aggressiveness may be developed to physical violence.

Table 9. Verbal aggressiveness target (way/distance) and appearance parameters (male students)

\begin{tabular}{lc}
\hline & insult with email/sms/letter (status) \\
\hline Heaviness (=weight/height) & $\mathbf{. 3 7 0}(*)$ \\
& $\mathbf{. 0 4 4}$ \\
\hline
\end{tabular}

** Correlation is significant at the 0.01 level (2-tailed).

* Correlation is significant at the 0.05 level (2-tailed).

In table 9, especially in the case of male students heaviness seems to be of utmost importance for preferring the most distant telecommunication way, namely sms/email, which mostly reduces even the thought of physical violence.

Table 10. Verbal aggressiveness target (way/distance) and appearance parameters (female students)

\begin{tabular}{|c|c|c|c|c|c|c|c|c|c|c|c|c|}
\hline & $\begin{array}{c}\text { insult } \\
\text { with } \\
\text { email/ } \\
\text { sms/letter } \\
\text { (in- } \\
\text { degree) }\end{array}$ & $\begin{array}{c}\text { insult } \\
\text { with } \\
\text { email/ } \\
\text { sms/letter } \\
\text { (status) }\end{array}$ & $\begin{array}{c}\text { insult with } \\
\text { email/sms/ } \\
\text { letter } \\
\text { (pagerank) }\end{array}$ & $\begin{array}{c}\text { insult } \\
\text { with } \\
\text { email/ } \\
\text { sms/ } \\
\text { letter } \\
\text { (autho- } \\
\text { rity) }\end{array}$ & $\begin{array}{l}\text { insult by } \\
\text { phone } \\
\text { (in- } \\
\text { degree) }\end{array}$ & $\begin{array}{c}\text { insult by } \\
\text { phone } \\
\text { (status) }\end{array}$ & $\begin{array}{l}\text { insult by } \\
\text { phone } \\
\text { (page- } \\
\text { rank) }\end{array}$ & $\begin{array}{l}\text { insult by } \\
\text { phone } \\
\text { (autho- } \\
\text { rity) }\end{array}$ & $\begin{array}{c}\text { insult } \\
\text { face-to- } \\
\text { face } \\
\text { (in-degree) }\end{array}$ & $\begin{array}{l}\text { insult } \\
\text { face-to- } \\
\text { face } \\
\text { (status) }\end{array}$ & $\begin{array}{c}\text { insult } \\
\text { face-to- } \\
\text { face } \\
\text { (page- } \\
\text { rank) }\end{array}$ & $\begin{array}{c}\text { insult } \\
\text { face-to- } \\
\text { face } \\
\text { (autho- } \\
\text { rity) }\end{array}$ \\
\hline \multirow[t]{2}{*}{$\begin{array}{l}\text { hair very } \\
\text { long }\end{array}$} & .144 & .094 & .113 & .196 & .176 & .165 & .106 & .249 & $.516(*)$ & $.545(*)$ & $.517(*)$ & .376 \\
\hline & .533 & .685 & .626 & .393 & .445 & .476 & .647 & .276 & .017 & .011 & .016 & .093 \\
\hline \multirow[t]{2}{*}{$\begin{array}{c}\text { hair } \\
\text { straight }\end{array}$} & $-.490(*)$ & $-.489(*)$ & $-.612(* *)$ & -.153 & $-.597(* *)$ & $-.629(* *)$ & $-.666(* *)$ & -.363 & $-.460(*)$ & $-.436(*)$ & $-.517(*)$ & -.376 \\
\hline & .024 & .024 & .003 & .508 & .004 & .002 & .001 & .106 & .036 & .048 & .016 & .093 \\
\hline \multirow[t]{2}{*}{ hair curly } & .335 & .340 & .219 & $.451(*)$ & .430 & $.488(*)$ & .361 & $.549(* *)$ & $.472(*)$ & $.587(* *)$ & $.527(*)$ & $.585(* *)$ \\
\hline & .138 & .131 & .341 & .040 & .052 & .025 & .108 & .010 & .031 & .005 & .014 & .005 \\
\hline \multirow[t]{2}{*}{ hair tied } & .375 & .358 & .329 & .262 & .274 & .184 & .241 & .166 & .394 & .282 & $.481(*)$ & .309 \\
\hline & .094 & .111 & .145 & .251 & .229 & .425 & .292 & .472 & .077 & .216 & .027 & .173 \\
\hline
\end{tabular}




\begin{tabular}{|c|c|c|c|c|c|c|c|c|c|c|c|c|}
\hline weight & $.434(*)$ & $.487(*)$ & $.452(*)$ & .253 & .249 & .239 & .284 & .116 & -.044 & -.130 & .027 & .031 \\
\hline & .050 & .025 & .040 & .268 & .277 & .297 & .213 & .616 & .850 & .576 & .907 & .894 \\
\hline $\begin{array}{l}\text { heaviness } \\
\text { (=weight/ }\end{array}$ & $.483(*)$ & $.514(*)$ & $.515(*)$ & .233 & .355 & .346 & .391 & . 183 & .015 & -.064 & .101 & .086 \\
\hline & .026 & .017 & .017 & .309 & .114 & .125 & .080 & .428 & .947 & .781 & .662 & .711 \\
\hline
\end{tabular}

In the table 10, numerous determinants which already have been described above play also a differentiated role in the selection of verbal assault way. The very long hair is a reason for face-to-face conflict (.516 to .545), proving its provocative effect, even if it protects against criticism on social milieu and background due to its imposing character. The straight hair proves once again to be the most neutral style which tends to reduce offensive contacts in all communication ways (-.460 to -.666). The curly hair can trigger offensive chats by email/sms (.451) and phone $(.488, .549)$ and mostly in face-to-face contacts $(.472$ to .587$)$, proving once again their visual-provocative effect. The same stands also for tied hair (.481) (s. above).

Weight (.434 to .487 ) and also heaviness (.483 to .515$)$ tend to reduce offense only to most distant and thereby safest way (email/sms), as everyone can realize the risk of physical violence development in case of face-to-face contact.

\subsection{Verbal Aggressiveness Target and Other Network Parameters}

Table 11. Verbal aggressiveness target (serious style) and other relations (whole sample)

(sum=indegree+status+pagerank+authority. This summarization is necessary in order to avoid unmanageable coefficients.)

\begin{tabular}{lccccc}
\hline & & $\begin{array}{c}\text { criticism on } \\
\text { intellectual } \\
\text { abilities } \\
\text { (sum) }\end{array}$ & $\begin{array}{c}\text { criticism on } \\
\text { criticism on } \\
\text { behavior } \\
\text { (sum) }\end{array}$ & $\begin{array}{c}\text { criticism on } \\
\text { appearance } \\
\text { (sum) }\end{array}$ & $\begin{array}{c}\text { social } \\
\text { milieu-back } \\
\text { ground } \\
\text { (sum) }\end{array}$ \\
\hline $\begin{array}{l}\text { desirable for personal/professional } \\
\text { (sum) }\end{array}$ & relation & .038 & .081 & .086 & $\mathbf{. 2 9 1}(*)$ \\
& & .789 & .565 & .542 & $\mathbf{. 0 3 5}$ \\
advising in humanities (sum) & -.079 & .010 & .009 & $\mathbf{. 2 9 3}(*)$ \\
& .575 & .942 & .948 & $\mathbf{. 0 3 3}$ \\
desirable for cooperation in research projects & $\mathbf{. 3 1 5}(*)$ & $\mathbf{. 3 4 4}(*)$ & $\mathbf{. 2 8 4}(*)$ & $\mathbf{. 2 9 2}(*)$ \\
(sum) & $\mathbf{. 0 2 2}$ & $\mathbf{. 0 1 2}$ & $\mathbf{. 0 3 9}$ & $\mathbf{. 0 3 4}$ \\
\hline
\end{tabular}

** Correlation is significant at the 0.01 level (2-tailed).

* Correlation is significant at the 0.05 level (2-tailed).

In table 11, one can see synergistic relations between verbal aggressiveness networks and other network properties. Being target of verbal aggressiveness concerning intellectual abilities is positively correlated with the acceptance one finds as possible partner in research projects (.315). This is understandable if one takes into account that persons who find such a wide resonance among the mass of students easily become targets of criticism because of jealousness and competition. Apart from that, if someone maintains or (desires to maintain) a good relation to particular persons with the perspective of a close future cooperation, he may already have developed enough familiarity or even intimacy to demand high standards from the potential partner and to express this demand in form of criticism (e.g. "I want you for partner but I would like you to think more carefully").

Regarding criticism on behavior issues, a person desirable as possible partner in research projects ought again to be "perfect" according to multifaceted criteria of other students who desire him. Thus, they tend to criticize him because sometimes he disappoints them (.344).

Those who are desired as research project partners become once again (.284) target of criticism, even on the occasion of their appearance. This can be understood as a reaction to jealousness or to intolerance of the others during the long cooperation and of course it can be encouraged by the familiarity and intimacy one develops during such cooperation.

The background as well as the social milieu seems to be a sensitive point even for those who have gained acceptance for a possible professional or personal relation (.291) or have gained reputation as advisers in humanity issues (.293) or as possible research project partners (.292). This can be respectively attributed to the demand of meeting specific standards for professional, research cooperation or friendship as well as the intimacy acquired through humanity-related discussions. 
Table 12. Verbal aggressiveness target (ironic/ cheating) and other relations (whole sample) (sum=indegree+status+pagerank+authority. This summarization is necessary in order to avoid unmanageable coefficients.)

\begin{tabular}{|c|c|c|}
\hline & irony (sum) & mockery/cheating (sum) \\
\hline \multirow[t]{2}{*}{ companion (sum) } & $.502(* *)$ & .220 \\
\hline & .000 & .114 \\
\hline \multirow[t]{2}{*}{$\begin{array}{l}\text { desirable for personal/professional relation } \\
\text { (sum) }\end{array}$} & $.531(* *)$ & .154 \\
\hline & .000 & .272 \\
\hline \multirow[t]{2}{*}{$\begin{array}{l}\text { desirable for cooperation in research projects } \\
\text { (sum) }\end{array}$} & $.669(* *)$ & $.321(*)$ \\
\hline & .000 & .019 \\
\hline \multirow[t]{2}{*}{ advising in natural sciences (sum) } & $.469(* *)$ & $.418(* *)$ \\
\hline & .000 & .002 \\
\hline \multirow[t]{2}{*}{ helpful without expecting return (sum) } & $.436(* *)$ & .224 \\
\hline & .001 & .107 \\
\hline \multirow[t]{2}{*}{ no helpful at all (sum) } & .013 & $.393(* *)$ \\
\hline & .926 & .004 \\
\hline
\end{tabular}

** Correlation is significant at the 0.01 level (2-tailed).

* Correlation is significant at the 0.05 level (2-tailed).

In table 12, the familiarization due to close companion in or outside campus (.502), the desire for personal or professional relation in future (.531) as well as for cooperation in research projects (.669) which are connected with demand for meeting specific standards, the reputation in advising about natural sciences leading to jealousness (.469) and the vulnerable character revealed by being helpful without expecting return (.436), are conducive to attracting ironic comments.

For similar reasons, mockery or cheating appear to be results of desirability for cooperation in research projects (.321) and resonance in advising about natural sciences issues (.418). However, mockery or cheating seems to be a defense or managing practice towards those who are not helpful at all (.393).

Table 13. Verbal aggressiveness target (way/distance) and other relations (whole sample)

(sum=indegree+status+pagerank+authority. This summarization is necessary in order to avoid unmanageable coefficients.)

\begin{tabular}{|c|c|c|c|}
\hline & $\begin{array}{c}\text { insult with } \\
\text { email/sms/letter (sum) }\end{array}$ & $\begin{array}{c}\text { insult by } \\
\text { phone (sum) }\end{array}$ & $\begin{array}{c}\text { insult } \\
\text { face-to-face } \\
\text { (sum) }\end{array}$ \\
\hline \multirow[t]{2}{*}{ companion (sum) } & .161 & $.375(* *)$ & $.441(* *)$ \\
\hline & .248 & .006 & .001 \\
\hline \multirow[t]{2}{*}{ desirable for personal/professional relation (sum) } & .171 & $.390(* *)$ & $.541(* *)$ \\
\hline & .220 & .004 & .000 \\
\hline \multirow[t]{2}{*}{ advising in humanities (sum) } & .073 & .228 & $.288(*)$ \\
\hline & .603 & .101 & .037 \\
\hline \multirow[t]{2}{*}{ advising in natural sciences (sum) } & $.292(*)$ & $.496(* *)$ & $.570(* *)$ \\
\hline & .034 & .000 & .000 \\
\hline \multirow[t]{2}{*}{ helpful without expecting return (sum) } & .230 & $.386(* *)$ & $.467(* *)$ \\
\hline & .098 & .004 & .000 \\
\hline \multirow[t]{2}{*}{ desirable for cooperation in research projects (sum) } & $.534(* *)$ & $.544(* *)$ & $.509(* *)$ \\
\hline & .000 & .000 & .000 \\
\hline
\end{tabular}

$* *$ Correlation is significant at the 0.01 level (2-tailed).

* Correlation is significant at the 0.05 level (2-tailed).

The results of table 13 seem also to be in general compatible with these of table 11 and 12 . Indeed, students who present the afore-mentioned network characteristics regarding socializing, trust etc. are susceptible to become addressees of verbal aggressiveness in any possible way (sms/email, phone, face-to-face). 


\subsection{Verbal Aggressiveness Target Extension}

Table 14. Verbal aggressiveness target (all types) extension (whole sample) (measured in in-degree)

\begin{tabular}{|c|c|c|c|c|c|}
\hline & $\begin{array}{c}\text { criticism on } \\
\text { behavior }\end{array}$ & $\begin{array}{l}\text { criticism on } \\
\text { appearance }\end{array}$ & $\begin{array}{c}\text { criticism on } \\
\text { social milieu/ } \\
\text { background }\end{array}$ & irony & $\begin{array}{l}\text { mockery/ } \\
\text { cheating }\end{array}$ \\
\hline \multirow[t]{2}{*}{ criticism on intellectual abilities } & $.782(* *)$ & $.743(* *)$ & $.586(* *)$ & $.590(* *)$ & $.480(* *)$ \\
\hline & .000 & .000 & .000 & .000 & .000 \\
\hline \multirow[t]{2}{*}{ criticism on behavior } & & $.790(* *)$ & $.640(* *)$ & $.564(* *)$ & $.497(* *)$ \\
\hline & & .000 & .000 & .000 & .000 \\
\hline \multirow[t]{2}{*}{ criticism on appearance } & & & $.675(* *)$ & $.482(* *)$ & $.305(*)$ \\
\hline & & & .000 & .000 & .026 \\
\hline \multirow[t]{2}{*}{ criticism on social milieu-background } & & & & $.550(* *)$ & $.306(*)$ \\
\hline & & & & .000 & .026 \\
\hline \multirow[t]{2}{*}{ irony } & & & & & $.621(* *)$ \\
\hline & & & & & .000 \\
\hline
\end{tabular}

** Correlation is significant at the 0.01 level (2-tailed).

* Correlation is significant at the 0.05 level (2-tailed).

In table 14, criticism concerning intellectual abilities, behavior and appearance seems to constitute a relatively cohesive core of verbal aggressiveness, as they present quite strong correlations with each other $(.782, .743, .790)$. These three types of aggressiveness present lower correlation to criticism on social milieu/background $(.586, .640, .675)$. This is understandable, as this last type of aggressiveness is thematically a quite different one from the former three types. Being aware of social milieu or background of someone necessitates much more (and more reliable) information than just having an idea of his intellectual abilities, behavior and appearance. These three aspects become already known (even superficially) as a rule from the first contact while social milieu and background need a much more detailed exploration in order to become familiar to the interlocutors.

Table 15. Verbal aggressiveness target (all types and way/distance) extension (whole sample)

(sum=indegree+status+pagerank+authority. This summarization is necessary in order to avoid unmanageable coefficients.)

\begin{tabular}{|c|c|c|c|c|c|c|c|c|}
\hline & $\begin{array}{c}\text { criticism on } \\
\text { behavior }\end{array}$ & $\begin{array}{l}\text { criticism on } \\
\text { appearance }\end{array}$ & $\begin{array}{c}\text { criticism on } \\
\text { social } \\
\text { milieu-backgro } \\
\text { und }\end{array}$ & irony & $\begin{array}{c}\text { mockery/ch } \\
\text { eating }\end{array}$ & $\begin{array}{l}\text { insult with } \\
\text { email/sms/l } \\
\text { etter }\end{array}$ & $\begin{array}{c}\text { insult by } \\
\text { phone }\end{array}$ & $\begin{array}{c}\text { insult } \\
\text { face-to-face }\end{array}$ \\
\hline \multirow[t]{2}{*}{$\begin{array}{c}\text { criticism on } \\
\text { intellectual } \\
\text { abilities }\end{array}$} & $.803(* *)$ & $.747(* *)$ & $.560(* *)$ & $.508(* *)$ & $.393(* *)$ & $.417(* *)$ & $.341(*)$ & .156 \\
\hline & .000 & .000 & .000 & .000 & .004 & .002 & .013 & .263 \\
\hline \multirow{2}{*}{$\begin{array}{l}\text { criticism on } \\
\text { behavior }\end{array}$} & & $.812(* *)$ & $.626(* *)$ & $.606(* *)$ & $.455(* *)$ & $.531(* *)$ & $.482(* *)$ & $.281(*)$ \\
\hline & & .000 & .000 & .000 & .001 & .000 & .000 & .041 \\
\hline \multirow[t]{2}{*}{$\begin{array}{l}\text { criticism on } \\
\text { appearance }\end{array}$} & & & $.637(* *)$ & $.533(* *)$ & .253 & $.407(* *)$ & $.386(* *)$ & .265 \\
\hline & & & .000 & .000 & .068 & .003 & .004 & .055 \\
\hline $\begin{array}{l}\text { criticism on } \\
\text { social milieu/ } \\
\text { background }\end{array}$ & & & & $.528(* *)$ & $.303(*)$ & $.321(*)$ & $.391(* *)$ & $.320(*)$ \\
\hline irony & & & & .000 & $\begin{array}{c}.027 \\
.518(* *) \\
.000\end{array}$ & $\begin{array}{c}.019 \\
.642(* *) \\
.000\end{array}$ & $\begin{array}{c}.004 \\
.738(* *) \\
.000\end{array}$ & $\begin{array}{c}.020 \\
.655(* *) \\
.000\end{array}$ \\
\hline $\begin{array}{l}\text { mockery/ } \\
\text { cheating }\end{array}$ & & & & & & $.539(* *)$ & $.573(* *)$ & $.499(* *)$ \\
\hline insult with & & & & & & .000 & .000 & .000 \\
\hline $\begin{array}{l}\text { email/sms/ } \\
\text { letter }\end{array}$ & & & & & & & $.661(* *)$ & $.525(* *)$ \\
\hline $\begin{array}{l}\text { insult by } \\
\text { phone }\end{array}$ & & & & & & & .000 & $\begin{array}{c}.000 \\
.795(* *)\end{array}$ \\
\hline & & & & & & & & .000 \\
\hline
\end{tabular}


** Correlation is significant at the 0.01 level (2-tailed).

* Correlation is significant at the 0.05 level (2-tailed).

In table 15, all types of serious ironic style aggressiveness are correlated with each other. In other words, there is an evident tendency to extend the aggressive action from one field (network) to another. The one who is criticized concerning his intellectual abilities, tends also to concentrate aggression on behavioral matters, appearance etc. The main attractor of aggression seems to be the targeting of weaknesses in intellectual abilities (numerous significant coefficients from .803 to .341 ). This can be attributed to the lack of defense capacity which is expected to derive from the (perceived) intellectual deficit (e.g. lack of quick reply).

Regarding the ways of expressing, the less significant correlations appear in face-to-face communication. This is understandable considering that this communicational pattern discourages aggression due to the physical distance (Storr, 1992) as well as due to the lack of time for careful processing and (re-)formulating responses.

Table 16. Verbal Aggressiveness Target Typology (Whole Sample)

\begin{tabular}{|c|c|c|c|c|c|}
\hline & $\begin{array}{c}\text { The } \\
\text { "general } \\
\text { black } \\
\text { sheep" }\end{array}$ & $\begin{array}{l}\text { The "con- } \\
\text { temptible } \\
\text { partner" }\end{array}$ & $\begin{array}{c}\text { The } \\
\text { "bagger" }\end{array}$ & $\begin{array}{l}\text { The } \\
\text { "victim of } \\
\text { mockers" }\end{array}$ & $\begin{array}{l}\text { The } \\
\text { "victim } \\
\text { of serial } \\
\text { critici- } \\
\text { zers" }\end{array}$ \\
\hline criticism on intellectual abilities (in-degree) & .718 & -.514 & .207 & -.004 & .011 \\
\hline criticism on intellectual abilities (status) & .764 & -.537 & .051 & .026 & .039 \\
\hline criticism on intellectual abilities (pagerank) & .718 & -.572 & .015 & .017 & -.056 \\
\hline criticism on intellectual abilities (authority) & .657 & -.454 & -.533 & -.105 & .107 \\
\hline criticism on behavior (in-degree) & .772 & -.368 & .317 & .069 & -.194 \\
\hline criticism on behavior (status) & .814 & -.383 & .231 & .111 & -.169 \\
\hline criticism on behavior (pagerank) & .792 & -.220 & .302 & .037 & -.314 \\
\hline criticism on behavior (authority) & .652 & -.414 & -.575 & -.132 & .020 \\
\hline criticism on appearance (in-degree) & .733 & -.475 & .247 & -.171 & -.165 \\
\hline criticism on appearance (status) & .807 & -.484 & .093 & -.126 & -.123 \\
\hline criticism on appearance (pagerank) & .794 & -.267 & .176 & -.169 & -.318 \\
\hline criticism on appearance (authority) & .611 & -.367 & -.630 & -.134 & -.018 \\
\hline criticism on social milieu-background (in-degree) & .650 & -.313 & .572 & -.113 & .241 \\
\hline criticism on social milieu-background (status) & .643 & -.267 & .596 & -.043 & .265 \\
\hline criticism on social milieu-background (pagerank) & .568 & -.212 & .656 & .054 & .128 \\
\hline criticism on social milieu-background (authority) & .424 & -.462 & .375 & -.058 & .558 \\
\hline irony (in-degree) & .815 & .229 & -.116 & -.083 & -.228 \\
\hline irony (status) & .845 & .220 & -.229 & -.082 & -.204 \\
\hline irony (pagerank) & .849 & -.156 & -.397 & -.033 & -.100 \\
\hline irony (authority) & .300 & .708 & .170 & -.330 & -.192 \\
\hline mockery/cheating (in-degree) & .726 & .299 & -.052 & .543 & -.131 \\
\hline mockery/cheating (status) & .660 & .328 & -.052 & .633 & -.028 \\
\hline mockery/cheating (pagerank) & .645 & .558 & .206 & .213 & -.148 \\
\hline mockery/cheating (authority) & .128 & .149 & .046 & .870 & .020 \\
\hline insult with email/sms/letter (in-degree) & .816 & .085 & -.301 & .119 & .227 \\
\hline insult with email/sms/letter (status) & .811 & -.026 & -.461 & .063 & .171 \\
\hline insult with email/sms/letter (pagerank) & .673 & .355 & -.083 & -.073 & .023 \\
\hline insult with email/sms/letter (authority) & .631 & -.252 & -.639 & .024 & .187 \\
\hline insult by phone (in-degree) & .777 & .466 & -.070 & -.023 & .199 \\
\hline insult by phone (status) & .733 & .558 & -.072 & -.037 & .143 \\
\hline insult by phone (pagerank) & .662 & .605 & .101 & -.135 & .116 \\
\hline insult by phone (authority) & .531 & .709 & -.070 & -.328 & .046 \\
\hline insult face-to-face (in-degree) & .727 & .519 & -.007 & .035 & .172 \\
\hline insult face-to-face (status) & .625 & 672 & .031 & .018 & .140 \\
\hline insult face-to-face (pagerank) & .585 & 677 & .284 & -.081 & -.015 \\
\hline insult face-to-face (authority) & .320 & .817 & .126 & -.320 & -.038 \\
\hline
\end{tabular}

Extraction Method: Principal Component Analysis. 
a 5 components extracted.

In table 16, an extensive and detailed typology of verbal aggressiveness is enabled. As already argued in table 14 and 15 , there mainly occur extensions (not subversions). Namely, if one becomes target of criticism in a certain field, then he tends to become a target in other fields and in several ways. This is the most regular type of verbal aggressiveness target and could be called "general "black sheep".

The "contemptible partner" is a more specified type. It is a target for irony or cheating/mockery which take place either by phone or even face-to-face. Such a target-person is not respectable. However, the others invest time on communicating with him, aiming e.g. at their personal entertainment or at testing their dominance.

The "bagger" type is derived from weaknesses mainly found out in his social milieu or background. It is a quite specific and autonomous type. This supports the argumentation of table 14, pointing out more clearly the social milieu/background as a peculiar feature separated from the other thematic fields of criticism. This feature not only necessitates particular exploration in order to reveal weaknesses but also constitutes an adequate basis for criticism. This feature is related to quite crucial information about personal -and private- aspects which may prove decisive for their socialization or even career. For this reason, it attracts so strongly and exclusively the focus of criticizers.

The "victim of mockers" could be regarded as a more specific version of the "contemptible partner". It is targeted not only for entertainment or testing general dominance but he becomes an addressee of mockery (or cheating) which is stronger form than simple irony. In contrast to irony which may be mutually amusing for both offender and offended, mockery/cheating can normally be amusing only for the former and humiliating only for the latter.

The most distinct feature constituting by itself an independent and also quite simple (one-variable-defined) type is this of high authority in social milieu/background-based criticism. It is differentiated from the "bagger", as it mainly attracts "serial" criticizers who systematically search for weaknesses in the social and personal life of other students.

\section{Conclusion}

The role of non-network determinants is noticeable. Gender-specific sensitiveness in social issues tends to protect female students from insult. Educational parameters such high grade of school graduation and parents' education level seem to protect against verbal aggressiveness while actual educational interest (in post-graduate study) seems to provoke criticism.

Social attitudes and patterns seem also to be of importance. Ignoring public opinion among students appears to function both as a reactive or intensifying factor in verbal aggressiveness. Avoiding intimacy with "many close friends" seems to be conducive to immunity to verbal aggressiveness.

Concerning features of appearance (physical or not) seem also to be noticeable determinants. Young (and not old-fashioned) appearance, imposing and eccentric appearance characteristics seem to protect against verbal aggressiveness. Particularly, big corporal size, dark skin colors seem to provoke insults in case of female students. Thus, aesthetic-based verbal aggressiveness is to be diagnosed.

Eminent economic state is also provocative as it implies pretentiousness.

Phone verbal aggressiveness tends to appear mainly among male students as they do not use phone while female students use phone for relaxation and criticism against third persons. In general, telecommunication means leaves more scope for aggressive expressiveness as it prevents physical violence.

Eminent qualities such as "good friend", "desirable partner" etc make someone an eminent target for verbal aggressiveness. Verbal aggressiveness presents a catholic character. Namely, a person who tends to be perceived by the others as "bad" from many or all points of view and to become a target in any possible way. This shows a tendency to generalize criticism in order to eliminate the image of a person and not to find out elements which could be regarded as "positive". Thus, there is a tendency for exercising destructive rather than constructive criticism through verbal aggressiveness (Infante, 1987, 1995; Infante \& Rancer 1996). On the other hand, one could argue that a "bad" person normally presents a deviant character which makes him "bad" in every aspect (Infante et al., 1994). In any case, there is a tendency for generalizing and extension. More specifically, weaknesses perceived in intellectual abilities constitute a verbal aggressiveness target core.

Finally, someone is not always assaulted with any kind and way of verbal aggressiveness. The kinds and ways of verbal aggressiveness tend to occur in certain combinations. Thereby, the following types of verbal aggressiveness targets are proposed: a) the "general "black sheep" who is assaulted in all possible ways and aspects, b) the "contemptible type" who is assaulted with irony, c) the "bagger" type who is vulnerable due to his social milieu and background, d) the "victim of mockers" and e) the "victim of serial criticizers". These types can be considered to correspond to different forms of behaviors and dominance incidents. 


\section{References}

Beatty, M. J., Zelley, J. R., Dobos, J. A., \& Rudd, J. E. (1994). Fathers' trait verbal aggressiveness and argumentativeness as predictors of adult sons' perceptions of fathers' sarcasm, criticism, and verbal aggressiveness. Communication Quarterly, 42, 407-415.http://dx.doi.org/10.1080/01463379409369946

Bekiari, A. (2012). Perceptions of instructors' verbal aggressiveness and physical education students' affective learning. Perceptual and Motor Skills, 115, 325-335.http://dx.doi.org/10.2466/06.11.16.PMS.115.4.325-335

Bekiari, A. (2014). Verbal aggressiveness and leadership style of sport instructors and their relationship with athletes' intrinsic motivation. Creative Education, 5(2), 114-121. http://dx.doi.org/10.4236/ce.2014.52018

Bekiari, A., Kokaridas, D., \& Sakellariou, K. (2005). Verbal aggressiveness of physical education teachers and students' self-reports of behaviour. Psychological Reports, 96, 493-498. http://dx.doi.org/10.2466/pr0.96.2.493-498

Bekiari, A., Digelidis, N., \& Sakellariou, K. (2006). Perceived verbal aggressiveness of coaches' in volleyball and basketball: A preliminary study. Psychological Reports, 103, 526-530. http://dx.doi.org/10.2466/pms.103.2.526-530

Bekiari, A., Kokaridas, D., \& Sakellariou, K. (2006). Associations of students' self-reports of their teacher's verbal aggression, intrinsic motivation, and perceptions of reasons for discipline in Greek physical education classes. Psychological Reports, 98, 451-461. http://dx.doi.org/10.2466/pr0.98.2.451-461

Brent, E., Thompson, A., \& Mirielli, E. (1995). Disambiguating verbal comments in social interaction: A computer model of meaning. The Journal of Mathematical Sociology, 20(2-3), 109-125. http://dx.doi.org/ 10.1080/0022250X.1995.9990157

Buontempo, J. T., Potrykus, H. G. \& Kaufman, A. I. (2006). A Symmetric Adaptive Model of Combat. The Journal of Mathematical Sociology, 30(2), 113-136. http://dx.doi.org/10.1080/00222500500333266

Costa, P. T., \& McCrae, R. R., (1980). Still stable after all these years: Personality as a key to some issues to adulthood and old age. In P. B. Baltes \& O. G. Brim (Eds). Life-span development and behaviour. New York: Academic Press.

Edwards, C., \& Myers, S. (2007). Perceived Instructor Credibility as a Function of Instructor Aggressive Communication. Communication Research Reports, 24(1), 47-53. http://dx.doi.org/10.1080/08824090601128141

Gorham, J., \& Christophel, D. M. (1992). Students' perceptions of teacher behaviours as motivating and demotivating factors in college classes. Communication Quarterly, 40, 239-252. http://dx.doi.org/10.1080/01463379209369839

Hassandra M., Bekiari A., \& Sakellariou, K. (2007). Physical education teacher's verbal aggression and student's fair play behaviors. The Physical Educator, 64, 94-101.

Infante, D. A. (1987). Aggressiveness. In J. C. McCroskey \& J. A. Daly (Eds.), Personality and interpersonal communication, Newbury Park, CA: Sage, 157-192.

Infante, D. A. (1988). Arguing constructively. Prospect Heights, IL: Waveland Press. Infante, D.A. (1995). Teaching students to understand and control verbal aggression. Communication Education, 44, 51-63.

Infante, D. A., \& Gorden, W. I. (1991). How employees see the boss: Test of an argumentative and affirming model of superiors' communicative behavior. Western Journal of Speech Communication, 55, 294-304. http://dx.doi.org/10.1080/10570319109374386

Infante, D. A., Myers S. A., \& Buerkel R. A. (1994). Argument and verbal aggression in constructive and destructive family and organization disagreements. Western Journal of Communication, 58, 73-84. http://dx.doi.org/10.1080/10570319409374488

Infante, D. A., \& Rancer, A. S. (1996). Argumentativeness and verbal aggressiveness: A review of recent theory and research. In B.R. Burleson (Ed.) Communication yearbook, 19 (pp.319-351). Beverly Hills, CA: Sage.

Katz, L. (1953). A New Status Index Derived from Sociometric Analysis. Psychometrika, 18, 39-43. http://dx.doi.org/10.1007/BF02289026

Kish, C., \& Woodard, R. (2005). The impact of positive motivational techniques by coaches on the achievement levels of men's junior college basketball players. Missouri Journal of Health, Physical Education, Recreation \& Dance, $15,6-15$.

Koss, M. P., Gidycz, Ch.A., \& Wisniewski, N. (1987). The scope of rape: Incidence and prevalence of sexual aggression and victimization in a national sample of higher education students. Journal of Consulting and Clinical Psychology, 55(2), 162-170. 
Martin, M. M., \& Anderson, C. M. (1997). Aggressive communication traits: How similar are young adults and their parents in argumentativeness, assertiveness, and verbal aggressiveness? Western Journal of Communication, 61, 299-314. http://dx.doi.org/10.1080/10570319709374579

Martin, M. M., Anderson, C. M., Burant, P. A., \& Weber, K. (1997). Verbal aggression in sibling relationships. Communication Quarterly, 45, 304-317. http://dx.doi.org/10.1080/01463379709370067

Martin, M. M., Anderson, C. M., \& Rocca, K. A. (2005). Perceptions of the adult sibling relationship. North American Journal of Psychology, 7, 107-116.

Martin, M. M., Heizel, A. D., \& Valencic, K. M. (1999). Verbal aggression in computer-mediated decision-making. The Annual Meeting of the National Communication Association, Chicago, 12-15 November 1999, $21 \mathrm{p}$.

Mouttapa, M; Valente, T., Gallaher, P., Rohrbach, L.A., Unger, J.B., (2004). Social network predictors of bullying and victimization. Adolescence, 39(154), 315-35.

Myers, S., \& Knox, R. (1999). Verbal aggression in the college classroom: Perceived instructor use and student affective learning. Communication Quarterly, 47(1), 33-45. http://dx.doi.org/10.1080/01463379909370122

Myers, S. A., \& Rocca, K. A. (2000). The relationship between perceived Instructor Communicator style argumentativeness, and verbal aggressiveness. Communication Research Reports, 17, 1-12. http://dx.doi.org/10.1080/08824090009388745

Popitz, H. (1992). Phaenomene der Macht (Phenomena of Power). J.C.B. Mohr Tuebingen.

Rancer, A. S., \& Infante, D. A. (1985). Relations between motivation to argue and the argumentativeness of adversaries. Communication Quarterly, 33, 209-218. http://dx.doi.org/10.1080/01463378509369599

Reynolds, R., \& Allen, W. (2003). The effects of coach communicative aggression on athlete learning and motivation. Conference Papers - International Communication Association.

Richmond, V. P., \& Gorham, J. (1996). Communication, learning, and affect in instruction. Edina, MN: Burgess.

Rocca K. A. (2004). Brief Report, College Student Attendance: Impact of Instructor Immediacy and Verbal Aggression. Communication Education, 53(2), 185-195. http://dx.doi.org/10.1080/03634520410001682447

Rocca, K. A., \& McCroskey, J. C. (1999). The interrelationship of student ratings of instructors' immediacy, verbal aggressiveness, homophily, and interpersonal attraction. Communication Education, 48, 308-316. http://dx.doi.org/10.1080/03634529909379181

Sabourin, T. C., Infante, D. A., \& Rudd, J. E. (1993). Verbal aggression in marriages: A comparison of violent, distressed but nonviolent, and nondistressed couples. Human Communication Research, 20, $245-267$. http://dx.doi.org/10.1111/j.1468-2958.1993.tb00323.x

Scheithauer, H., Hayer, T., Petermann, F., \& Jugert, G. (2006) Physical, Verbal, and Relational Forms of Bullying Among German Students: Age Trends, Gender Differences, and Correlates. Aggressive Behavior, 32, $261-275$. http://dx.doi.org/10.1002/ab.20128

Smith - Lovin, L. (1987). The affective control of events within settings. The Journal of Mathematical Sociology, 13(1-2), 71-101. http://dx.doi.org/10.1080/0022250X.1987.9990027

Storr A. (1992). Human Aggression. Middlesex: Penguin Books.

Valencic, K. M., Beatty, M. J., Rudd, J. E., Dobos, J. A., \& Heisel, A. D. (1998). An empirical test of a communibiological model. Communication Quarterly, 46, 327-341. http://dx.doi.org/10.1080/01463379809370105

Wiggins, B., \& Heise, D. R. (1987). Expectations, intentions, and behavior: Some tests of affect control theory. The Journal of Mathematical Sociology, 13(1-2), 153-169. http://dx.doi.org/10.1080/0022250X.1987.9990030

Xie, H., Farmer, T. W., Cairns, B.D. (2003). Different forms of aggression among innercity African-American children: Gender, configurations and school social networks. Journal of School Psychology, 41(5), 355-375. http://dx.doi.org/10.1016/S0022-4405(03)00086-4

\section{(cc) $\mathrm{BY}$}

This work is licensed under a Creative Commons Attribution 3.0 License. 